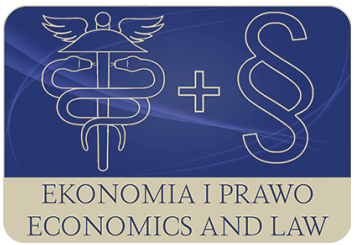

EKONOMIA I PRAWO. ECONOMICS AND LAW

Volume 18, Issue 1, March 2019

p-ISSN 1898-2255, e-ISSN 2392-1625

www.economicsandlaw.pl

ORIGINAL ARTICLE

received 04.09.2017; revised 13.01.2019; accepted 31.03.2019

Citation: Stelter, B. (2019). The management approach of the new institutional economics. Ekonomia $i$

Prawo. Economics and Law, 18(1): 73-81. doi:10.12775/EiP.2019.006.

\title{
The management approach of the new institutional economics
}

\author{
BARTOSZ STELTER \\ Nicolaus Copernicus University in Toruń, Faculty of Economic Sciences and Management, \\ Department of Logistics, ul. Gagarina 13a, 87-100 Toruń, Poland \\ 曰 stelter@doktorant.umk.pl \\ (iD) orcid.org/0000-0002-0576-4857
}

\begin{abstract}
Motivation: The role of corporations in the modern economy is extremely important, in addition, the widely observed oligopolistic markets gave birth to the need for the formulation of the theoretical concept of undertaking explanatory way of large companies, with particular emphasis on the basic objective of the company and the role they play in the markets. The aim of the work is to present alternatives to the traditional neoclassical concept of enterprises, management theory and their critical assessment, as well as an indication of the application values of managerial recognition proceedings of enterprises with an emphasis on the form of its operation. In this work there were presented mainly the views of O.E. Williamson, on the aggregate concept of operation of the company in the light of the theory of transaction costs.

Aim: The aim of the article is the analysis of enterprise under the new institutional economics in respect of management science, and to show the intermingling of economics and management, and an attempt to justify the need of their connection. In the article there has been used the world literature and it has been examined for adequacy and being up-to-date to the theme proposed in the article.

Results: Most of the discussion in the mainstream of new institutional economics provides indications on the ways and means of raising the efficiency of the sector by striving to achieve aka the institutional balance. New institutional economics offers a fresh look at the decision-making process in organizations; it shows the complexity of this process and indicates the items that have not been previously included, and whose role in this process can be significant. Institutional analysis applies to phenomena and processes, which occur in organizations and its use can lead to beneficial results for them.
\end{abstract}


Keywords: utility management; the concept of O.E. Williamson; the concept of R. Coase; transaction costs; agency theory; multi-divisional form

JEL: D23; H77

\section{Introduction}

R. Coase in his well-known paper on the nature of the firm, argued that organizations exist because they offer a better way of managing risk that is inherent in certain market transactions for resources. R. Coase argued, in effect, that the existence of firms suggests that hierarchical coordination of certain kinds of resources exchanges within organizations results in lower costs that bear the risk of using markets for coordinating those exchanges. R. Coase's ideas were extended by economist O.E. Williamson, who developed the 'transaction cost' framework for explaining why certain economic exchanges are coordinated within organizations rather than through the markets. (Sanchez \& Heene, 2004).

\section{A review of the literature on the new institutional economics in the management approach}

Economic, social and environmental are the three aspects of economic crisis that begun in the mid-2007 and has lasted, with more or less force, to the present day. The economic crisis in the financial markets and banks has its analogue not only in crisis of economics, but also in the science of management. The teachings of management thinking need the transformation from monism to pluralism and the engagement of ideas of many different directions of thought in the management, finance and economics. The social context of economics is bringing it close to social psychology, political science and law. The mainstream theory gets two important developments through institutional terminology. The first, economics gains a pluralist methodological perspective as long as the social context of economics explaining economic behaviour has been transferred to economics. The second, economics will have a chance to produce mainstream theory's ideas and economic policy of its own by approaching the social context which has lost (Orhan, 2016, p. 206). The above can be explained by the popularity of new institutional economics including the possibility of its influence on the development of management sciences. It can be concluded that the new institutional economy is dominated by thinking about governance in the 21st century. Scientific research was of great interest in constitutional economics and political economy, which, together with the closely related areas of the broadly understood new institutional economy, will become more dominant in the next century (Buchanan, 1991). The new institutional economy is trying to take into account the phenomena and problems that bring about economic development. It recognizes the need to reduce transaction costs, which may be due to an increased complexity of business processes. The new institu- 
tional economy devotes much attention to the enterprise and here the proposed changes are the greatest. This has shifted the focus of the research problem from the analysis of the generation and allocation of resources to the coordination of activities within the company and its relations with the environment. O.E. Williamson (1986), defined the essence of the changes in the enterprise. According to the new institutional economics, the concept of a company as a production function has replaced or extended the concept of the company as a management structure (Boehlke, 2010).

The essence of the economics of strategic management can be considered in two dimensions. The first is the content dimension. It stems from the fact that the overwhelming scope of content defining the management process is strictly economic, or it refers more or less to economic matter. An important property of this matter is its plasticity, which stimulates progress in strategic management and in this sense permeates permanently into the theory and practice of shaping business development. The example of this may be the adoption of transaction cost concepts and the growing popularity of institutional economics (R. Coase) and neoinstitutional economics (O.E. Williamson), which may also be inspirational in the area of strategic management. In the O.E. Williamson operationalization of Coasian transactions cost analysis, a hierarchical organization is a method for controlling opportunism in the presence of bounded rationality and asset specificity (Davidson et al., 2016, p. 16). Another example of saturating the management of content derived from the economic trend is the resource approach. Fundamentals of today's leading strategic management school, initiated by J. Barney (1991), was born in the 50s of the 20th century in the works of economists such as E. Penrose or K.J. Arrow, and the main idea is derived from D. Ricardo.

The second dimension of compounds with the high development potential and increased impact of the economy on strategic management in the future is a methodological dimension. The basics of cognitive goals and practical goals of strategic management have never been the strong ones. Relatively modest management output when it comes to developing your own research methods limits its applicability. Ephemeral metaphors, archetypes, paradoxes, or the use of specific cases as a pattern of conduct leave some inadequate workmanship. For example, from the analysis and strategic planning stage up to the stage of verification of the effects of the implemented strategy, the procedures used there, economic algorithms, their logic and compactness are still an attractive area for conceptual use.

The question of vertical integration - which stages of the value chain should be included within a firm's boundaries and why - has been studied by many schools for almost 100 years (Barney \& Hesterly, 2010). The reason why this question has been of such interest was first articulated by the Nobel prize-winning economist R. Coase. In a famous article originally published in 1937, R. Coase asked a simple question: given how efficiently markets can be used to organize economic exchanges among thousands, even hundreds of thou- 
sands, of separate individuals, why should markets, as a method for managing economic exchanges, ever be replaced by firms? In markets, almost as if by magic, A. Smith's 'invisible hand' coordinates the quantity and quality of goods and services produced with the quantity and quality of goods and services demanded through the adjustment of prices - all without a centralized controlling authority. However, in firms, centralized bureaucrats monitor and control subordinates who, in turn, battle with each other for 'turf' and control of inefficient internal 'fiefdoms'.

Although the term capitalist economy often refers to the market economy, it actually consists of two forms of economic organization. The first is a market mechanism ${ }^{1}$ in which individuals and companies make independent decisions that are determined by price movements. The second is the management mechanism $^{2}$ of companies, where decisions on production and allocation of resources are made by the management. What determines which actions should be taken by company forces and which by market? R. Coase replies that the relative cost is decisive. Markets do not work cost-free. Costs of exploration include the purchase or sale, the costs of negotiating and preparing the contract, the costs of monitoring the correctness of the terms of the contract, the costs of the arbitration, the costs of the litigation are just some examples of costs included in transaction costs (Grant, 2010).

It has become a widespread policy to organize multi-business firms into strategic business units (SBUs). This organizational structure is often referred to as the M-form (Williamson, 1975). Each strategic business unit is given the responsibility to serve the particular demands of one business area. The business units are labelled 'strategic'; each is driven by its own business level strategy. The challenge for managers is to find the most effective and efficient forms of integration between two or more separate business units. Three key integration mechanisms can be distinguished (Wit \& Meyer, 2010): centralization, coordination and standardization.

Much attention in the literature has been paid to the issue of vertical integration of activities. It is also referred to as 'internalization' because firms decide to perform activities inside the firm, instead of dealing with outside suppliers and buyers. In general, companies will strive to integrate upstream or downstream activities where one or more of the following conditions are deemed important (Wit \& Meyer, 2010): operational coordination, increased bargaining power learning curve advantages, implementing system-wide changes and avoidance of transaction costs. Reaching a deal with a supplier or a buyer and transferring the goods or services to the required location may be accompanied by significant direct costs. These contracting costs can include the expenses of negotiations, drawing up a contract, financial transfers, packaging distribu-

1 The coordination role of the market mechanism referred to as the 'invisible hand', according to A. Smith, of 18th century economist, does not require conscious planning.

2 A. Chandler (1977), described the administrative mechanism as the 'visible hand' because according to him, the coordination involves the active planning. 
tions and insurance. Add to these the search costs, required to locate and analyse potential new suppliers or buyers, as well as the policing costs, which are incurred to check whether the contract is being met according to expectations and to take actions against those parties not living up to their contractual responsibilities. If a firm vertically integrates, many of these costs can be avoided, leading to potential savings (Williamson, 1975). Firms with stronger technological capabilities face a higher risk of appropriation from exchange partners, and may therefore continue to prefer vertical integration, even in contexts where high political risks increase the institutional costs of hierarchical governance (Dorobantu et al., 2016, p. 121).

One of the most important frameworks for making choices about whether or not to vertically integrate is called transaction cost economics (Williamson, 1975). Transaction costs economics is based on the assertion that, if a particular exchange is seen as being potentially valuable, then governance mechanisms whether market, intermediate, or hierarchical have two purposes:

- to minimize the threat that exchange partners will be unfairly exploited in an exchange;

- to do this at the lowest possible cost.

In many economic exchanges, despite strong incentives to cooperate in order to realize these gains from trade, there can also exist strong incentives to cheat. This threat of cheating can exist in any economic exchange, including those managed through market and hierarchical forms of governance. In transaction cost economics, this is called the threat of opportunism (Barney, 2007). Opportunism exists whenever parties who exchange exploit the vulnerabilities of exchange partners. Minimizing the threat of opportunism is not the only thing that exchange partners need to consider. They must also concern themselves with the cost of managing opportunism. Governance is not costless. In general, the more elaborate the form of governance, the greater is the direct cost of governance, that is, the direct costs of market forms of governance are less than the direct cost of intermediate forms of governance, and the direct cost of intermediate forms of governance are less than the direct costs of hierarchical forms of governance. Thus, if all exchange partners have to concern themselves with minimizing the cost of governance in managing their economic exchanges, they would always choose market forms of governance. Exchange partners need to concern themselves with both minimizing the threat of opportunism and minimizing the cost of governance (Williamson, 1975). Thus, rational economic actors will choose just level of governance needed to minimize the threat of opportunism in a particular exchange.

One of the best-known explanations of when vertical integration can be valuable focuses on using vertical integrations to reduce the threat of opportunism (Williamson, 1975). Opportunism exists when a firm is unfairly exploited in an exchange (Walter \& Yusen, 2015).

The most common organizational structure for implementing a corporate diversification strategy is the $\mathrm{M}$-form, or multidivisional structure. In the mul- 
tidivisional structure, each business that the firm engages in is managed through a division (Barney \& Hesterly, 2010, p. 222). Different firms have different names for these divisions - SBUs, business groups or companies. Whatever their names, the divisions in an $\mathrm{M}$-form organization are true profit-and-loss centres: profits and losses are calculated at the level of the division in these firms.

Performance can be compared across business units, resources can be allocated rationally among units, and the performance of the firm is enhanced as a consequence. As O.E. Williamson (1986), has observed: 'the organization and operation of the large enterprise along the lines of the M-form (multiunit form) favours goal pursuit and least-cost behaviour more nearly associated with the neoclassical profit maximization hypothesis than does the U-form (unitary form) organizational alternative'. The advantages of multiunit firms, however, have proved temporary. Firms have grown, and the problems experienced by unitary firms have reappeared within business units of multiunit firms. Indeed, from the mid-1970s on, there have been indications that driving financial measures downward from the firm as a whole to its business units postpones but does not solve performance measurement problems caused by large size and complexity.

Under the M-form administrative structure, local governments have full budgetary and financial autonomy, including revenue collection autonomy. The role of the central manager is minimal, limiting its oversight to measuring performance and promoting cooperation. However, under the U-form administrative structure, the central government has full budgetary and decision autonomy, and it is the single revenue collection entity. In this arrangement, the role of the local manager is minimal, limiting its actions to implementing policies and programs decided at the center, using resources that are also transferred from the center even if a share of those resources were collected locally (Bustamante, 2016, p. 563).

O.E. Williamson (1986), believed that the unitary form provided the solution to two key problems of co-ordinate order 1 . Resource allocation and 2. The resolution of the agency problem. The basic problem of the agency is that the payers (shareholders) require the company to maximize value, while their agents (managers) are more interested in salaries, security and authority. Considering the limited power of shareholders to discipline managers and the weaknesses of management control, the headquarters of a company with a divisional structure can act as an intermediary between shareholders and branch managers and enforce the achievement of the financial goals. When branches are assigned the role of profit centres, financial results can be monitored immediately by the head office, and branch managers may be responsible for operational errors. According to O.E. Williamson (1986), multinational corporations can maximize profit more effectively than specialist firms with significant corporate headquarters advantages over a single management unit, i.e. the corporate headquarters has much better access to information about a company's operations and it is easier for the inefficient managers to replace inefficient managers. 


\section{Conclusion}

Discussions on the relationship between management sciences and new trends in economics are alive not only in the scientific community but also in managerial practice. It may be believed that not only management science but also neoclassical economics do not keep pace with the increasing complexity of mechanisms in the economy in general, including in enterprises. The world we are in is at least multi-level and multi-channel, not to add multi-zone (Glachant, 2014, p. 172). How does this new institutional approach fit in with neo-classical theory? It begins with the scarcity hence competition postulate; views economics as a theory of choice subject to constraints; employs price theory as an essential part of the analysis of institutions; and sees changes in relative prices as a major force inducing change in institutions (North, 2016, p. 74). All trends in the development of economic and managerial sciences and paradigms often balancing the boundaries of economics, management and finance are a response to growing difficulties in explaining the increasingly dangerous economic phenomena. It may seem that in research little space of management professionals devote various problems to the organizations themselves. Indeed, many doubts have been made in the neoclassical economy, and as detailed within the new institutional economy, the author's view, the synergy of economic sciences and modern management tools gives relatively good opportunities for a comprehensive description and analysis of the functioning of the enterprise.

The economic crisis has shown how important are regulations, and research by O.E. Williamson, transaction prices showed that the question of what to do and what market you need to be addressed straight-let it does this institution, which allows cheaper to arrange a replacement. But it is also worth mentioning, that some authors claim therefore the path of institutional change is not possible to predict (Dzionek-Koztowska et al., 2015, p. 16). The role of the State is creating such regulations that will reduce the cost of trade. An example would be the purchase of a plot by the investor in a prestigious district. This involves a risk, there may be some claims, for example, unordered mortgage. Therefore, the buyer spends resources on a good firm, that will check it all through just before transaction commits. They invests a lot before the transaction to reduce the risk. These are the transaction costs. What can the state do? It can lower transaction costs - reduce the cost of ex post, and so the risk of the transaction, given the cost of ex ante, i.e. expenditure on lawyers for checking the status of the proprietary of the ground.

Ending these theoretical considerations, hoping that the practical implications it is worth quoting the seemingly obvious but rich in content: the goal of each transaction is to maximize efficiency while minimizing costs (Williamson, 1990). 


\section{References}

Barney, J.B. (1991). Firm resources and sustained competitive advantage. Journal of Management, 17(1). doi:10.1177/014920639101700108.

Barney, J.B. (2007). Gaining and sustaining competitive advantage. Upper Saddle River: Prentice Hall.

Barney, J.B., \& Hesterly, W.S. (2010). Strategic management and competitive advantage: concepts and cases. New Jersey: Prentice Hall.

Boehlke, J. (2010). Firma we wspótczesnej myśli ekonomicznej: studium teoretyczno-metodologiczne. Torun: Wydawnictwo UMK.

Buchanan, J.M. (1991). Economics in the post-socialist century. The Economic Journal, 101(404). doi:10.2307/2233831.

Bustamante, A.V. (2016). U-form vs. M-form: how to understand decision autonomy under healthcare decentralization? Comment on decentralization of health services in Fiji: a decision space analysis. International Journal of Health Policy and Management, 5(9). doi:10.15171/ijhpm.2016.73.

Chandler, A.D. (1977). The visible hand: the managerial revolution in American business. Cambridge: Harvard University Press.

Davidson, S., De Filippi, P., \& Potts, J. (2016). Disrupting governance: the new institutional economics of distributed ledger technology. SSRN Electronic Journal. doi:10.2139/ssrn.2811995.

Dorobantu, S., Kaul A., \& Zelner, B. (2016). Nonmarket strategy research through the lens of new institutional economics: an integrative review and future directions. Strategic Management Journal, 38(1). doi:10.1002/ smj. 2590 .

Dzionek-Kozłowska, J., \& Matera, R. (2015). New institutional economics' perspective on wealth and poverty of nations. Concise review and general remarks on Acemoglu and Robinson's concept. Annals of the Alexandru Ioan Cuza University - Economics, 62(sl). doi:10.1515/aicue-2015-0032.

Glachant, J-M. (2014). Governance in network industries: lessons learnt from new institutional economics. Competition and Regulation in Network Industries, 15(2). doi:10.1177/178359171401500204.

Grant, R.M. (2010). Contemporary strategy analysis. Hoboken: Wiley, Chichester: John Wiley.

North, D.C. (2016). Institutions and economic theory. The American Economist, 61(1). doi:10.1177/0569434516630194.

Orhan, S.S. (2016). In the new institutional economics approach R. Coase and Law, D. North and social psychology context: pluralist approach opportunities in economics. Sosyoekonomi, 24(28). doi:10.17233/se.88088.

Sanchez, R., \& Heene, A. (2004). The new strategic management: organization, competition, and competence. New York: Wiley \& Sons.

Walter, L.W, \& Yusen, L.X. (2015). Delivering customer value through procurement and strategic sourcing: a professional guide to creating a sustainable supply network. Upper Saddle River: Pearson FT Press. 
Williamson, O.E. (1975). Markets and hierarchies: analysis and antitrust implications. New York: New York Free Press.

Williamson, O.E. (1986). Economic organizations: firms, markets and policy control. London: Wheatsheaf Books.

Williamson, O.E. (1990). Economic Organization. New York: New York University Press.

Wit, B., \& Meyer, R. (2010). Strategy synthesis: resolving strategy paradoxes to create competitive advantage. Andover: South-Western Cengage Learning.

\section{Acknowledgements}

Author contributions: author has given an approval to the final version of the article.

Funding: this research was fully funded by the Nicolaus Copernicus University in Torun, Faculty of Economic Sciences and Management (grant no. 2599-E). 
